\title{
Diesel Soot - Catalyzed Production of Reactive Oxygen Species: Cooperative Effects with Bisulfite
}

\author{
S. C. Hippeli and E. F. Elstner \\ Institut für Botanik und Mikrobiologie, Biochemisches Labor, Technische Universität München, \\ Arcisstraße 21, D-8000 München 2, Bundesrepublik Deutschland \\ Z. Naturforsch. 44c, 514-523 (1989); received December 1, 1988 \\ Dedicated to Professor Achim Trebst on the occasion of his 60th birthday \\ Diesel Soot Particles, Reactive Oxygen Species, Chemiluminescence, Sulfite, Air Pollutants \\ The fragmentation of KMB (4-(methylthio)-2-oxobutyric acid) as an indicator reaction for the \\ production of strong oxidants is catalyzed by diesel soot particles in the light. This reaction \\ operates also in the dark and can be strongly stimulated by the addition of sulfite. The cooperative \\ activity of diesel soot particles (DP) and sulfite also bleaches the carotenoid crocin. This molecule \\ represents a model for both the groups of plant pigments as well as polyene structures embedded \\ as flexible backbones in cellular membranes. Enhanced chemiluminescence generated by \\ linolenic acid in the presence of either tert-butylhydroperoxide or hydrogenperoxide is detected in \\ the presence of both DP and $\mathrm{HSO}_{3}{ }^{-}$. Luminescence originates from singlet oxygen or chemically \\ excited molecules such as triplet ketones and is thus a valuable indicator for peroxidation of lipids \\ involved in membrane damage. All reactions were inhibited by SOD (superoxide dismutase) \\ whereas catalase had no effect.
}

\section{Introduction}

Several well known compounds such as $\mathrm{NO}_{\mathrm{x}}$ and $\mathrm{SO}_{2}$ play an outstanding role in air pollution. Diesel exhaust is another airborne pollutant with growing importance.

From the environmental standpoint, diesel engines have low hydrocarbon and carbon monoxide emissions. $\mathrm{NO}_{\mathrm{x}}$ levels are comparable to those of gasoline-driven cars equipped with catalysts. Of special importance are the particulate emissions, however, which are 30 to 70 times higher than those from catalyst equipped spark ignition engines, arising to approximately $1 \mathrm{~g}$ per kilometer [1]. The soot particles are small in size (less than $0.5 \mu \mathrm{m}$ ), easily respirable, and have carbon cores with a very large surface area onto which a variety of organic compounds is adsorbed. $15-65 \%$ of the mass consists of extractable organic material such as polycyclic aromats, nitro aromats and quinones. Number and structures of these compounds depend on the type of engine and

Abbreviations: KMB, 4-(methylthio)-2-oxobutyric acid; DP, diesel soot particles; SOD, superoxide dismutase; LA, linolenic acid; $t$-BuOOH, tert-butyl hydroperoxide.

This work was supported by Bayerisches Staatsministerium für Landesentwicklung und Umweltfragen.

Reprint requests to Prof. Dr. E. F. Elstner.

Verlag der Zeitschrift für Naturforschung, D-7400 Tübingen $0341-0382 / 89 / 0500-0514 \$ 01.30 / 0$ the mode of its operation and may thus be extremly different [1-3].

Several investigators demonstrated that organic extracts from DP are mutagenic in both bacterial and mammalian cell systems. Especially products from the reaction between diesel fuel and $\mathrm{NO}_{2}$ seem to be highly cytotoxic and mutagenic $[4,5]$.

Chronic effects and tumor induction in the respiratory tracts of animals were observed after inhalation of unfiltered diesel engine emissions [6].

A heavy load of soot particles was found in long term dieselexposed lungs of animals, initiating tissue reactions including inflammations and fibrotic lesions. The massive accumulation of soot correlates very well with the deterioration of the alveolar lung clearence mechanism [7].

Mammalian cell mutagenesis bioassays capable of detecting gene mutations, DNA damage and chromosomal aberrations have confirmed the mutagenic activity of diesel exhaust [8].

The carcinogenic activity of polycyclic hydrocarbons obtained in diesel emission has been correlated with their ability to form free radicals [9].

Nachtman [10] demonstrated, that 1-nitropyrene (the main nitro-PAH in diesel exhaust) generates reactive oxygen radicals such as superoxide radical anions in the presence of rat lung microsomes.

Much is known on the other hand about $\mathrm{SO}_{2}$ as one main air pollutant and its role in generating "acid rain". 
During the nasal passages and in the lung, $\mathrm{SO}_{2}$ is rapidly hydrated forming sulfite or bisulfite depending on the $\mathrm{pH}$ of the relevant media. At physiological $\mathrm{pH}$, bisulfite, $\mathrm{HSO}_{3}{ }^{-}$, predominates. It was shown, that bisulfite incubated with prostaglandine synthase and arachidonic acid, 15-hydroperoxyarachidonic acid or $\mathrm{H}_{2} \mathrm{O}_{2}$ results in the formation of the reactive sulfur trioxide anion radical $\left(\mathrm{SO}_{3}{ }^{-}\right)$. This free radical was detected with electron spin resonance technique and spin trapping [11]. Prostaglandine synthase is widespread in biological systems including the lungs.

In green plants chlorophyll destruction has been described as a cooxidative process during the reaction between linolenic acid hydroperoxide and bisulfite [12]. The authors suggested, that alkoxy radicals formed as metabolites might be responsible for the destruction of chlorophyll through free radical mechanisms.

Diesel soot particles on the other hand are able to catalyze ethylene release from KMB [13], which is a sensitive indicator for the production of strong oxidants such as the $\mathrm{OH}^{\cdot}$ radical, singlet oxygen, transitionmetal-oxygen or peroxide complexes of the Fenton type [14].

In the present communication we report that

a. ethylene release from KMB mediated by diesel soot particles is stimulated synergistically by sulfite. This cooperative activity between soot particles and sulfite is further shown to

b. bleach crocin, a water soluble model substance representing carotenoids and polyene structures, and

c. initiate chemiluminescence of linolenic acid or in the presence of preformed peroxides such as tertbutylhydroperoxide or $\mathrm{H}_{2} \mathrm{O}_{2}$.

\section{Materials and Methods}

\section{Materials}

All chemicals were of the highest grade of purity available (Merck). KMB, SOD, linolenic acid and $\mathrm{H}_{2} \mathrm{O}_{2}(30 \%)$ were obtained from Sigma; Catalase was from Boehringer and $t$ - $\mathrm{BuOOH}(70 \%)$ from $\mathrm{Al}$ drich-Chemie. Crocin was isolated from commercially available saffron as earlier described [15]. Diesel soot particles were carefully removed with a small brush from the exhaust pipe of a fire brigade motor car (Magirus, Fire brigade Lohr/Main). All experi- ments with DP were done with the same batch of soot, in order to warrant standardized conditions for the experiments.

KMB-Fragmentation: The formation of ethylene from KMB was determined by gas chromatography as described previously [16].

The reaction mixture contained in $2 \mathrm{ml}$

\begin{tabular}{lrl} 
phosphate buffer & \multicolumn{2}{c}{$0.1 \mathrm{~m} / \mathrm{pH} 7.8$} \\
$\mathrm{KMB}$ & 5 & $\mu \mathrm{mol}$ \\
$\mathrm{DP}$ & 400 & $\mu \mathrm{g}$ \\
$\mathrm{HSO}_{3}{ }^{-}$ & 0.5 & $\mathrm{mM}$ \\
$\mathrm{SOD}$ & 100 & $\mathrm{U}$ \\
catalase & 100 & $\mathrm{U}$ \\
$\mathrm{H}_{2} \mathrm{O}$ & 2 & $\mathrm{ml}$
\end{tabular}

The reactions were done at $37^{\circ} \mathrm{C}$ in the light (30 klux) or at the same temperature in the dark. Standard deviations represent $n=6$. Crocin bleaching was followed at $440 \mathrm{~nm}$ in a UVIKON-810 spectrophotometer (Kontron, Eching). Crocin destruction was also determined by registrating the absorption spectra between 350 and $550 \mathrm{~nm}$.

The reaction mixtures were either illuminated for 30 min ( 30 klux) or incubated in the dark in a water bath at $37^{\circ} \mathrm{C}(n=6)$.

The reaction mixture containd in $2 \mathrm{ml}$

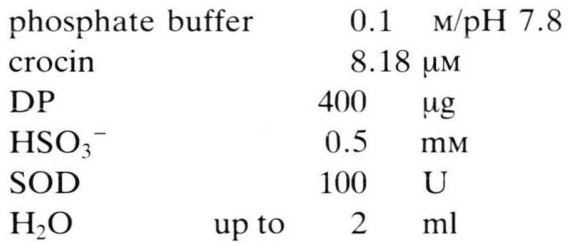

Chemiluminescence was measured at $37{ }^{\circ} \mathrm{C}$ in a Berthold Biolumat LB $9500 \mathrm{~T}$.

The reaction mixtures contained in $2 \mathrm{ml}$ phosphate buffer

$0.1 \mathrm{M} / \mathrm{pH} 6.8$ in reactions with $t$-BuOOH and $\mathrm{H}_{2} \mathrm{O}_{2}$ pH 6.3 in reactions with linolenic acid

linolenic acid,

\begin{tabular}{lrr}
$t$ - $\mathrm{BuOOH}$ or $\mathrm{H}_{2} \mathrm{O}_{2}$ & \multicolumn{2}{c}{$11.3 \mu \mathrm{M}$} \\
$\mathrm{DP}$ & $1-400$ & $\mu \mathrm{g}$ \\
$\mathrm{HSO}_{3}{ }^{-}$ & 0.5 & $\mathrm{~mm}$ \\
$\mathrm{SOD}$ & 100 & $\mathrm{U}$ \\
catalase & 100 & $\mathrm{U}$ \\
$\mathrm{H}_{2} \mathrm{O}$ & 2 & $\mathrm{ml}$
\end{tabular}


$0.1 \mathrm{~g}$ linolenic acid was dissolved in $40 \mathrm{ml}$ borate buffer, $0.2 \mathrm{M}, \mathrm{pH} 9.0$, containing $0.1 \mathrm{ml}$ Tween 20 and $0.26 \mathrm{ml} 1 \mathrm{~N} \mathrm{NaOH}$.

Light emissions arising from the reactions were integrated over 60 seconds. The reactions were started by automatic injection of LA-, $t$ - $\mathrm{BuOOH}-$ or $\mathrm{H}_{2} \mathrm{O}_{2}$ solutions via a Dispensor LB 95-C-300.

The data shown are differences between the values with and without $\mathrm{LA}, t-\mathrm{BuOOH}$ or $\mathrm{H}_{2} \mathrm{O}_{2}$. Standard deviations were calculated for $n=8$.

\section{Results}

\section{A. KMB-Fragmentation}

As shown in Fig. 1 the release of ethylene from $\mathrm{KMB}$ both in the light and in the dark is strongly stimulated by addition of both DP and sulfite. In the light DP or sulfite release 5 and $7.3 \mathrm{nmol}$ ethylene, respectively. In combination the amount of ethylene is increased by a factor of nearly 6 as compared to the sum of ethylene produced by the individual reactions. In the dark DP alone is not active in the release of ethylene from KMB. Sulfite alone causes the formation of $1.5 \mathrm{nmol}$ ethylene whereas both compounds together enhance the KMB-fragmentation 10 -fold yielding $16 \mathrm{nmol}$ ethylene.

Both light and dark reactions of the combined system are terminated after approximately $30 \mathrm{~min}$ (Fig. 2).

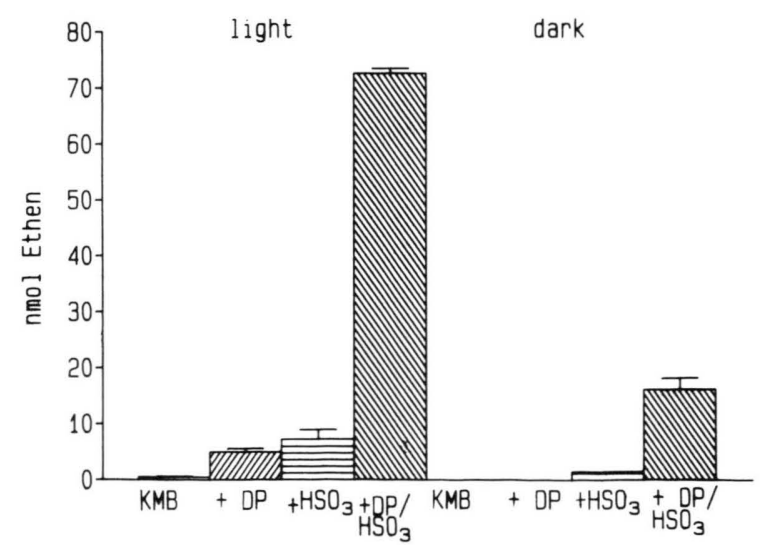

Fig. 1. Ethylene release from KMB by DP and sulfite in the light and in the dark. Reaction mixtures contained in a total volume of $2 \mathrm{ml}: 2.5 \mathrm{~mm} \mathrm{KMB}, 400 \mu \mathrm{g} \mathrm{DP}, 0.5 \mathrm{~mm}$ sulfite, $0.1 \mathrm{~m}$ phosphate buffer ( $\mathrm{pH} 7.8$ ).

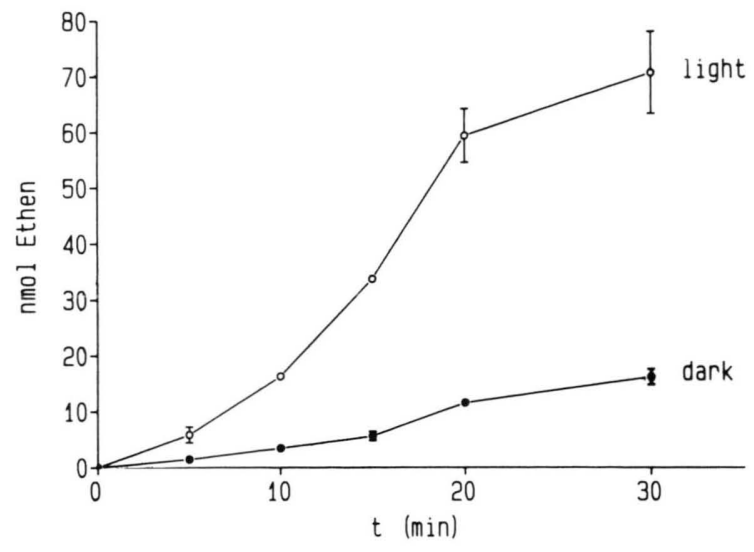

Fig. 2. Formation of ethylene from KMB under the influence of DP/sulfite. Reaction mixtures as described for Fig. 1. Standard deviations for $n=6$.

The effects of antioxidative enzymes are shown in Fig. 3. SOD inhibits ethylene formation in the light as well as in the dark yielding $65 \%$ and $95 \%$ inhibition, respectively, after $30 \mathrm{~min}$ whereas catalase has no effect.

\section{B. Crocin-bleaching}

Crocin destruction by illuminated DP-suspensions is shown in Fig. 4. After 30 min crocin without additions undergoes negligible degradation. In the presence of DP the decrease in absorbance followed at $440 \mathrm{~nm}$ is about $13 \%$; in the presence of sulfite the

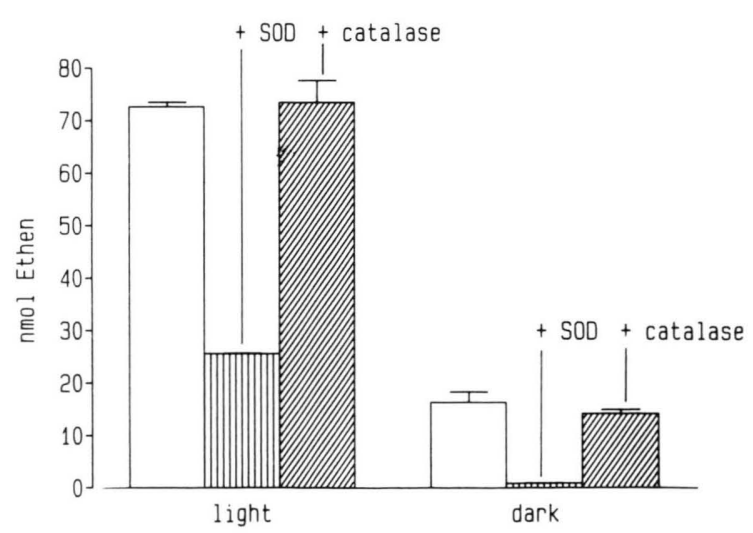

Fig. 3. Influence of SOD and catalase on KMB-fragmentation by DP/sulfite. The reaction mixtures (total volume of $2 \mathrm{ml}$ ) contained: $2.5 \mathrm{~mm} \mathrm{KMB}, 400 \mu \mathrm{g}$ DP, $0.5 \mathrm{~mm}$ sulfite, $100 \mathrm{U}$ SOD, $100 \mathrm{U}$ catalase, $0.1 \mathrm{~m}$ phosphate buffer $(\mathrm{pH}$ 7.8). 


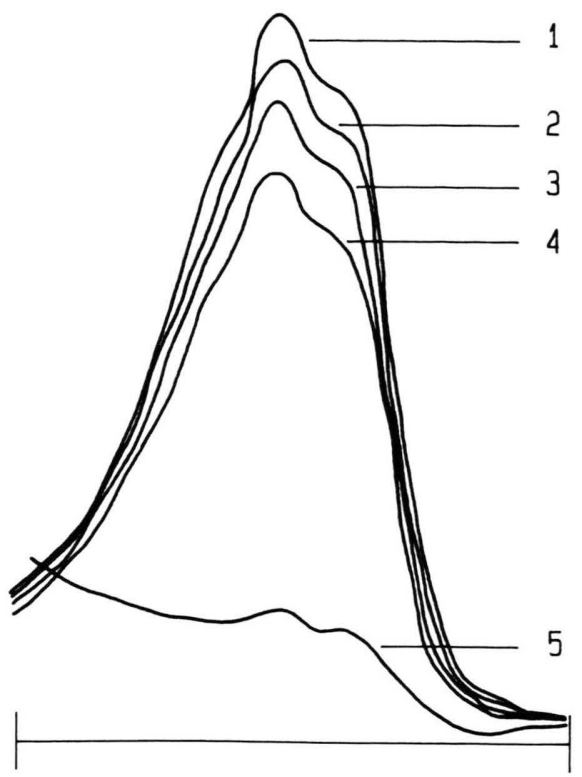

1: Crocin,

2: Crocin,

3: Crocin + DP,

4: Crocin + sulfite,

0 min, E $440 \mathrm{~nm}: 0.978$

$30 \mathrm{~min}, \mathrm{E} 440 \mathrm{~nm}: 0.929$

$30 \mathrm{~min}, \mathrm{E} 440 \mathrm{~nm}: 0.853$

Plsulfite, $30 \mathrm{~min}, \mathrm{~m}, 440 \mathrm{~nm}$. 0.750

5: Crocin + DP/sulfite, $30 \mathrm{~min}, \mathrm{E} 440 \mathrm{~nm}: 0.145$
Fig. 4. Comparison of the spectra of crocin treated by DP, sulfite and DP/sulfite. The reaction mixture (total volume of $2 \mathrm{ml}$ ) was as follows: $8.18 \mu \mathrm{M}$ crocin, $400 \mu \mathrm{g}$ DP, $0.5 \mathrm{~mm}$ sulfite, $0.1 \mathrm{~m}$ phosphate buffer (pH 7.8). decay is about $23 \%$ in $30 \mathrm{~min}$. Total destruction of the carotenoid is observed within $30 \mathrm{~min}$ in the presence of both DP and sulfite.

The time kinetics of the light and dark reactions are shown in Fig. 5 and 6. In the presence of both DP and sulfite crocin is bleached in the light by $88 \%$ and in the dark by $72 \%$. The single substances degrade crocin by about $25 \%$ where the effects in the light are more pronounced. SOD inhibits crocin bleaching by $\mathrm{DP} /$ sulfite in the light as well as in the dark reaction yielding $46 \%$ inhibition in the light and $86 \%$ in the dark.

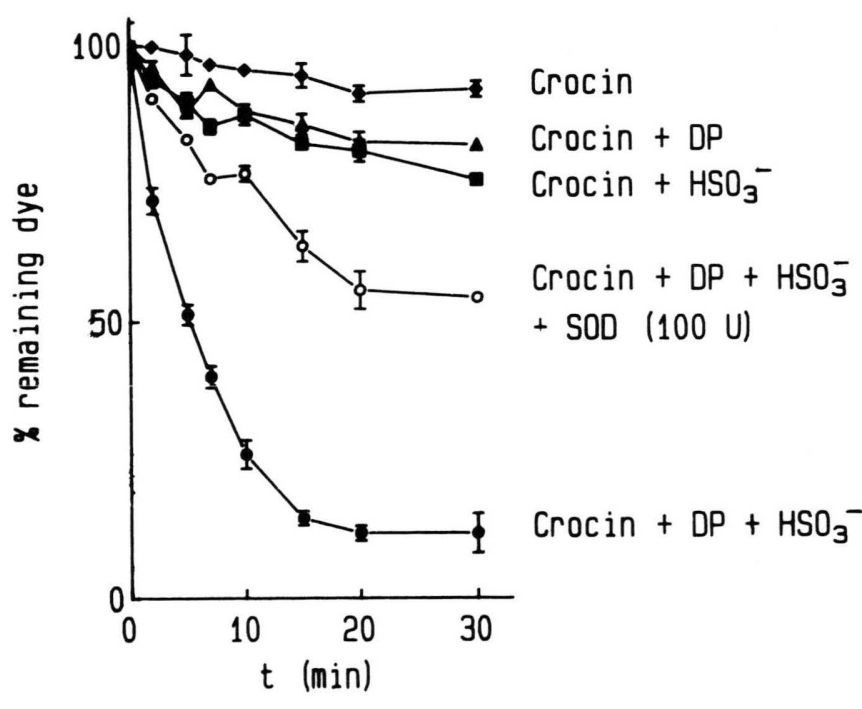

Fig. 5. Crocin bleaching in the light and the effect of SOD. The reaction mixture (total volume of $2 \mathrm{ml}$ ) was as described for Fig. 4. 100 U SOD were added. Standard deviations for $n=6$. 


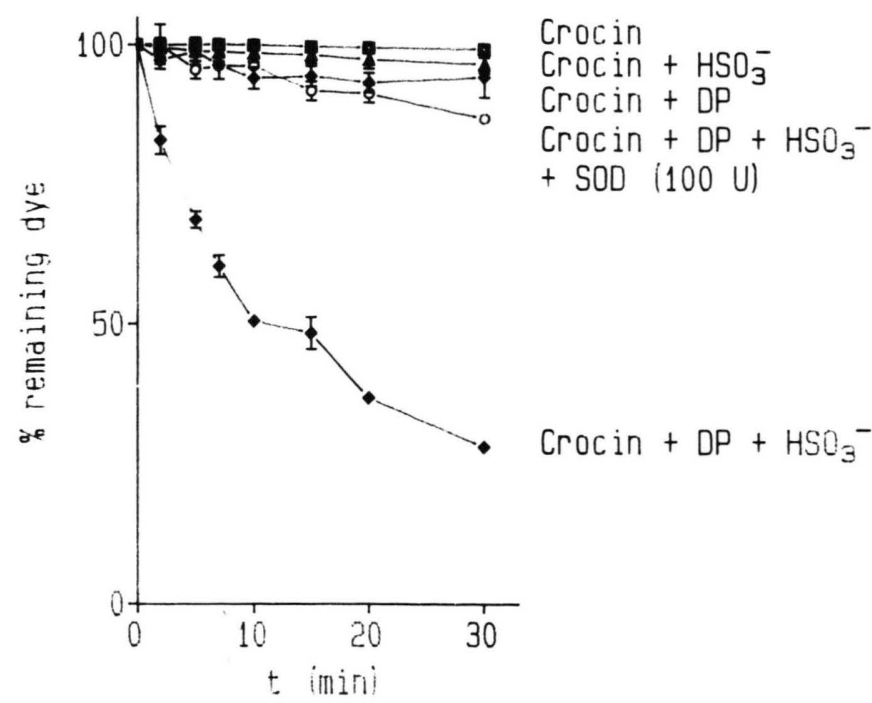

Fig. 6. Crocin bleaching in the dark. Reaction mixtures and standard deviations are identical to those in Fig. 5.

\section{$C$. Chemiluminescence generated by reactions}

between $\mathrm{DP} /$ sulfite and $\mathrm{LA}, t-\mathrm{BuOOH}$ or $\mathrm{H}_{2} \mathrm{O}_{2}$

Lipid peroxidation proceeds via a free radical mechanism generating a series of reactive intermediates including alkoxyl radicals, peroxyl radicals and hydroperoxides. Treatment of linolenic acid with DP and sulfite causes light emission with 4.222 "counts" during the first minute. The degree of light emission depends on the age of the LA solution (and thus probably on the stage of its autoxidation) and on the $\mathrm{pH}$. The strongest light emissions were observed at acid $\mathrm{pH}$ and aged LA solutions (data not shown). The $\mathrm{pH}$ finally chosen for this reaction was 6.8 , the $\mathrm{pH}$ optimum for the reactions with $t$ - $\mathrm{BuOOH}$ or $\mathrm{H}_{2} \mathrm{O}_{2}$. Fig. 7 shows, that pure LA or LA with added DP caused no light emission, LA plus sulfite to some degree. Like in the other test systems (KMB-fragmentation and crocin bleaching) catalase has no effect on light emission whereas SOD inhibits by about $40 \%$. Conducting the same experiment with $t$ $\mathrm{BuOOH}$ or $\mathrm{H}_{2} \mathrm{O}_{2}$ in place of LA, we found almost identical results. The light emission was reduced during the reactions between sulfite and $t \mathrm{BuOOH}$ or $\mathrm{H}_{2} \mathrm{O}_{2}$ in comparison to the light production of the complete system, were 11,000 counts were recorded with $t-\mathrm{BuOOH}$, and 1500 counts with $\mathrm{H}_{2} \mathrm{O}_{2}$. SOD inhibited the light emission in the $t$ - $\mathrm{BuOOH}$-system

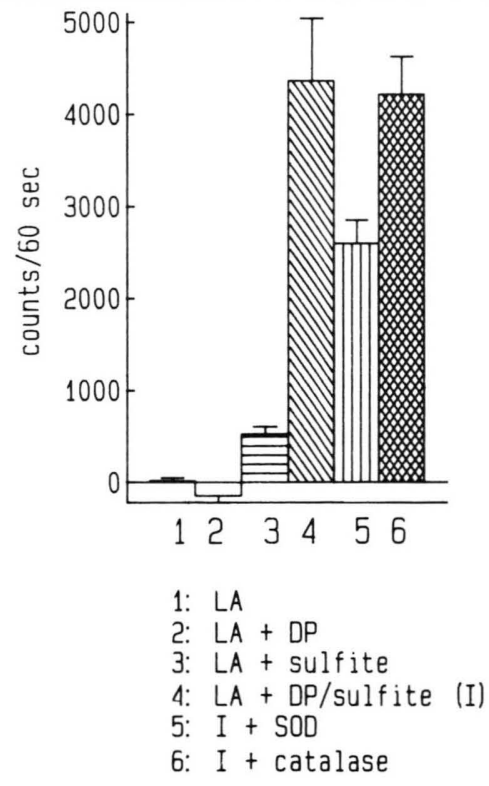

Fig. 7. Chemiluminescence by LA treated with DP and sulfite. Experimental conditions were as described in Materials and Methods. Reaction mixtures contained in a total volume of $2 \mathrm{ml}: 11.3 \mu \mathrm{m} \mathrm{LA}, 400 \mu \mathrm{g}$ DP, $0.5 \mathrm{~mm}$ sulfite. $100 \mathrm{U}$ SOD, $100 \mathrm{U}$ catalase, $0.1 \mathrm{~m}$ phosphate buffer $(\mathrm{pH}$ 6.3). (1), LA; (2), LA with DP; (3), LA with sulfite; (4), LA with DP/sulfite (= I); (5), I with SOD; (6), I with catalase. Standard deviations for $n=8$. 


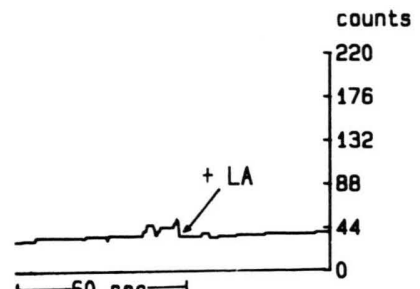

1: LA

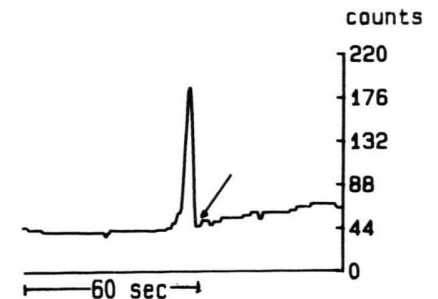

2: $L A+D P$

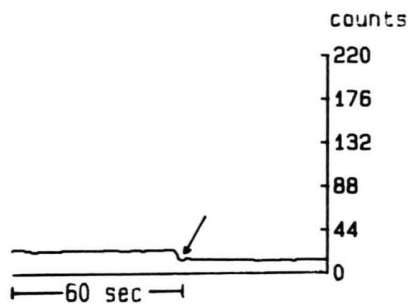

3: LA + sulfite

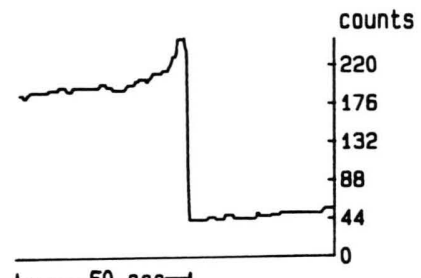

—60 sec -1

4: LA + DP/sulfite (I)

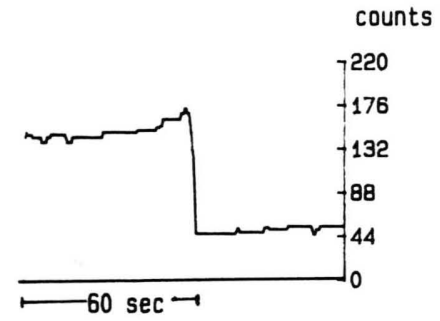

5: $I+S O D$

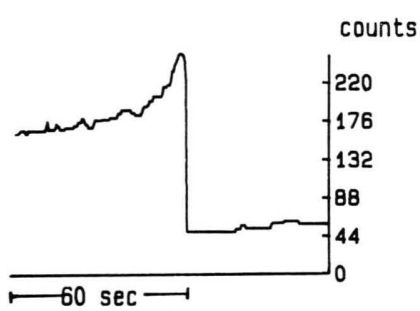

6: I + catalase.

Fig. 8. Kinetics of the reactions between LA and DP and sulfite. The reaction mixture was as described in Fig. 7. Numbers 1-6 were in accordance with those in Fig. 7. Experimental conditions were as indicated in Materials and Methods.

by $30 \%$, in the $\mathrm{H}_{2} \mathrm{O}_{2}$-system by $97 \%$ whereas catalase had no effect in the first system. The decrease of chemiluminescence in the $\mathrm{H}_{2} \mathrm{O}_{2}$-system in the presence of catalase is trivially a result of the enzymatic destruction of the added $\mathrm{H}_{2} \mathrm{O}_{2}$. The light emission of the reaction between $t$ - $\mathrm{BuOOH}$ and $\mathrm{DP} /$ sulfite depends on the DP-concentration. Fig. 11 and 12 show that already $5 \mu \mathrm{g}$ DP significantly catalyze the light emission. At a concentration of $200 \mu \mathrm{g} / 2 \mathrm{ml} \mathrm{DP}$ a saturation of the reaction is observed.

Fig. 8, 10 and 14 show the reaction kinetics of the three chemiluminescence systems. The numbers in the individual kinetic graphs are in accordance with the numbers in the corresponding figures (Fig. 7, 9, 13) representing the integrated areas underlying these curves. Chemiluminescence increases rapidly after adding $\mathrm{LA}, t$-BuOOH or $\mathrm{H}_{2} \mathrm{O}_{2}$ to the reaction mixtures containing DP and sulfite (exp.-No. 4) and decreases slowly. The inhibiting effect of SOD is shown as a lower peak of light emission (No. 5) whereas the kinetics in the presence of catalase (No. 6) are identical with those of the complete system (No. 4).

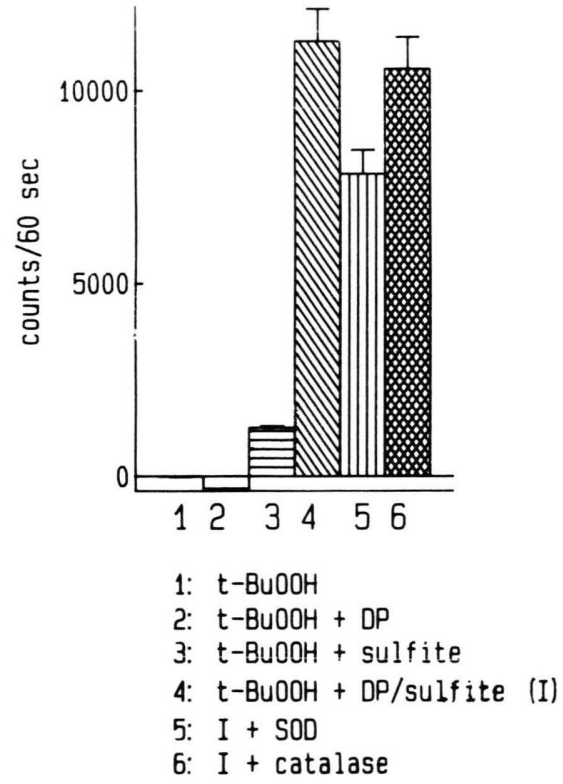

Fig. 9. Chemiluminescence by $t$-BuOOH treated with DP and sulfite. Reaction mixture was as described for Fig. 7. LA was replaced by $t$-BuOOH $(11.3 \mu \mathrm{M}) .0 .1 \mathrm{~m}$ phosphate buffer ( $\mathrm{pH}$ 6.8) was used. 


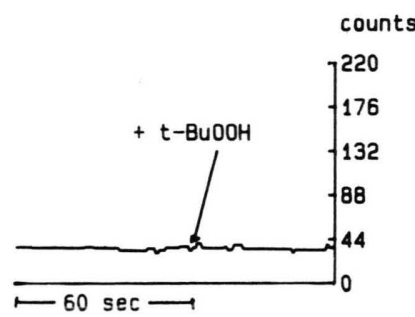

1: $\mathrm{t}-\mathrm{BuOOH}$

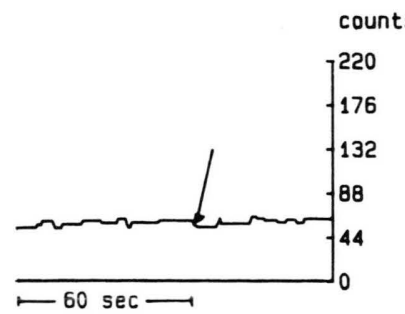

2: $t-B U O O H+D P$

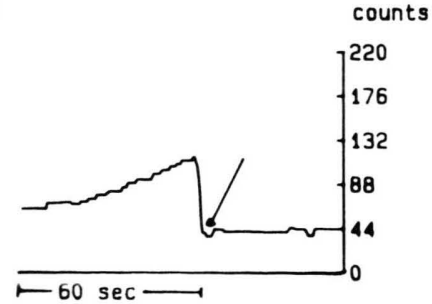

3: t-BuOOH + sulfite

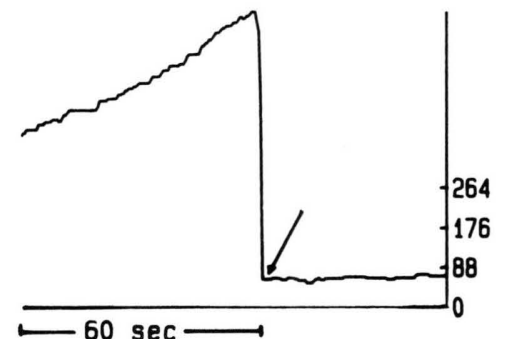

$60 \mathrm{sec}$

4: $t-B u O O H+D P / s u l f i t e$ (I)

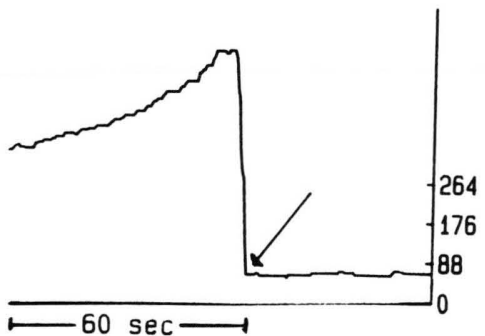

$6: 1+$ catalase

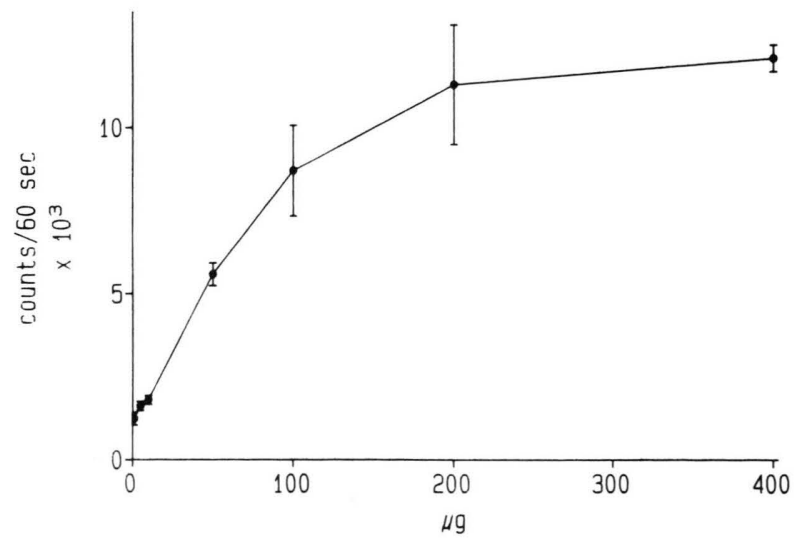

Fig. 11 and 12. Light emissions in the system $t$-BuOOH/ $\mathrm{DP} /$ sulfite in dependence on DP concentrations. The reaction mixtures (total volume of $2 \mathrm{ml}$ ) contained: $11.3 \mu \mathrm{M} t$ -
Fig. 10. Kinetics of chemiluminescence by $t$-BuOOH. Reaction mixtures and combinations (No 1-6) were as described for Fig. 7; $t$-BuOOH instead of LA.

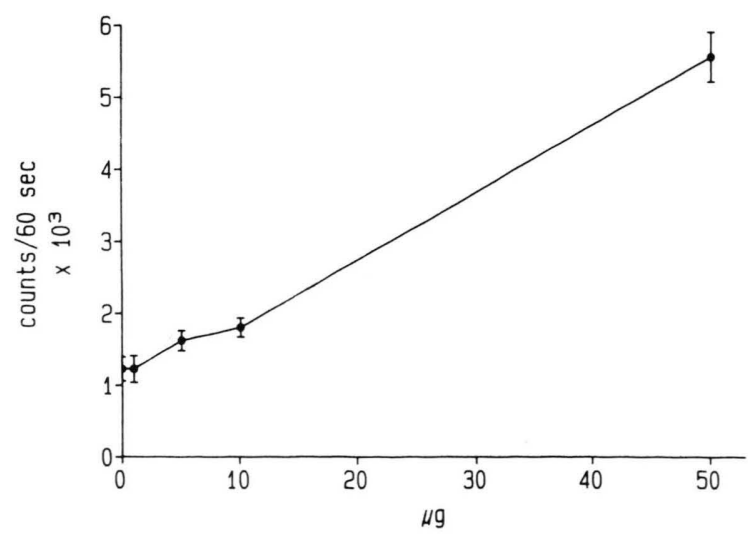

BuOOH, $0.5 \mathrm{~mm}$ sulfite, $0-400 \mu \mathrm{g}$ DP, $0.1 \mathrm{~m}$ phosphate buffer ( $\mathrm{pH}$ 6.8). Standard deviations for $n=6$. 


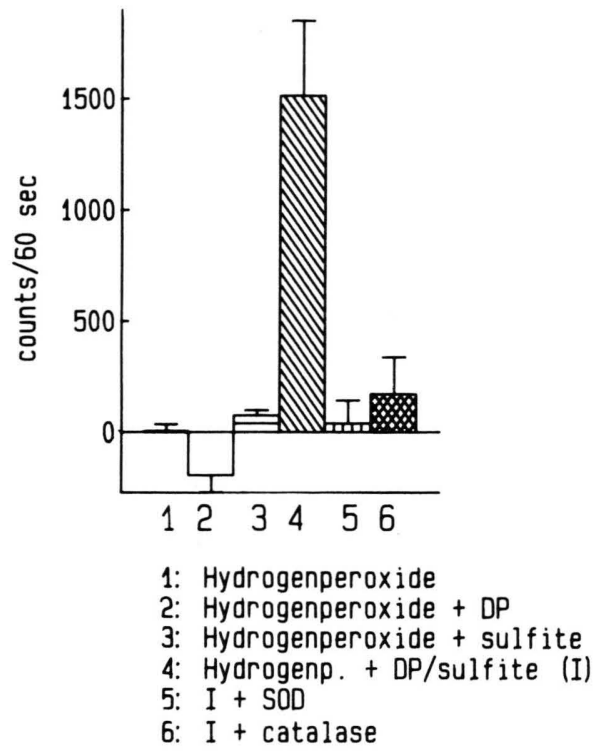

Fig. 13. Chemiluminescence of the combination $\mathrm{H}_{2} \mathrm{O}_{2} / \mathrm{DP} /$ sulfite. The reaction mixture was as indicated for Fig. 7. In place of $\mathrm{LA}, \mathrm{H}_{2} \mathrm{O}_{2}(11.3 \mu \mathrm{M})$ was used; $0.1 \mathrm{~m}$ phosphate buffer ( $\mathrm{pH}$ 6.8); standard deviations for $n=8$.

\section{Discussion}

In three different test systems the combinations of DP and sulfite yield synergistic effects of molecular destructions, which were inhibited by SOD whereas catalase had no influence. KMB-Fragmentation and crocin bleaching also proceed as light reactions were the single substances as well as the combinations were stimulatory. It is remarkable, that the light reactions were only partially inhibited by SOD whereas the dark reactions were inhibited by nearly $100 \%$. This suggests, that light and dark reactions are due to different mechanisms where superoxid radical anion is involved and $\mathrm{H}_{2} \mathrm{O}_{2}$ seems to be of no importance.

In all systems sulfite supports the degradations probably by acting as electron donor. Peiser and Yang [12] reported that, during $\mathrm{HSO}_{3}{ }^{-}$-driven lipid peroxide degradation, $\mathrm{HSO}_{3}{ }^{--}$radicals, alkoxy radicals and $\mathrm{O}_{2}{ }^{-}$radicals were generated as follows:

$$
\begin{aligned}
& \mathrm{HSO}_{3}{ }^{-}+\mathrm{LOOH} \stackrel{k 1}{\longrightarrow} \mathrm{LO}^{\cdot}+\mathrm{HSO}_{3}{ }^{-}+\mathrm{OH}^{-} \\
& \mathrm{HSO}_{3}{ }^{-}+\mathrm{O}_{2}+\mathrm{H}_{2} \mathrm{O} \stackrel{k 2}{\longrightarrow} \mathrm{SO}_{4}{ }^{2-}+\mathrm{O}_{2}{ }^{--}+3 \mathrm{H}^{+}
\end{aligned}
$$

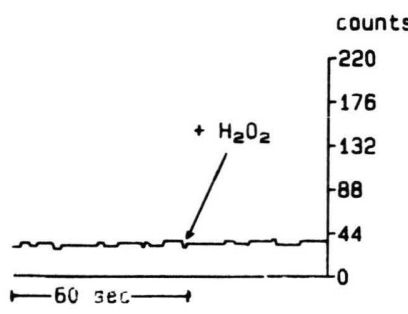

1: $\mathrm{H}_{2} \mathrm{O}_{2}$

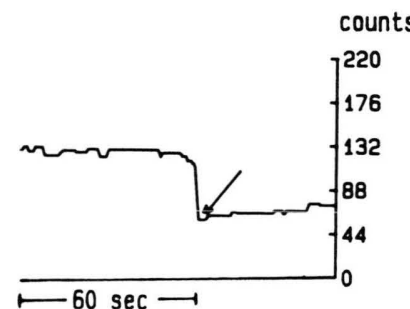

4: $\mathrm{H}_{2} \mathrm{O}_{2}+$ DP/sulfite (I)

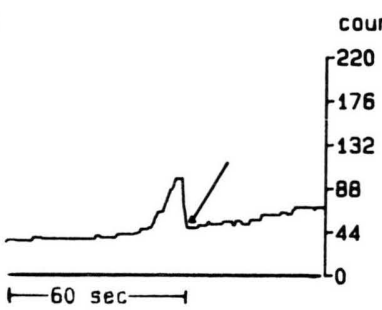

2: $\mathrm{H}_{2} \mathrm{O}_{2}+\mathrm{DP}$

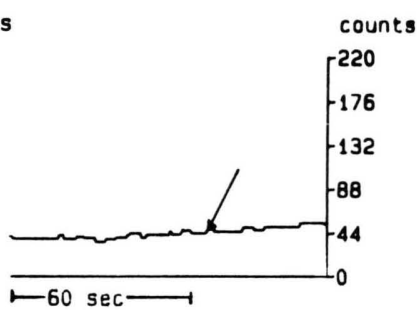

3: $\mathrm{H}_{2} \mathrm{O}_{2}+$ sulfite

Fig. 14. Kinetics of chemiluminescence produced by $\mathrm{H}_{2} \mathrm{O}_{2}$, DP and sulfite. The reaction mixture and the combinations (No. 1-6) were as described for Fig. 7. In place of $\mathrm{LA}, \mathrm{H}_{2} \mathrm{O}_{2}$ was used. $0.1 \mathrm{~m}$ phosphate buffer had a $\mathrm{pH}$ of 6.8 . 
Our results suggest that the reaction konstant $k 1$ is influenced by the catalytic function of DP thus accelerating radical formation.

Iwaoka et al. [17] indicated, that chemiluminescence during lipid peroxidation in rat liver microsomes was due to singlet oxygen generation. Further investigations with $t$ - $\mathrm{BuOOH}$ under anaerobic conditions showed, that the luminescence might be based on the following generalized reaction sequence of hydroperoxide breakdown:

$$
\mathrm{LOOH} \stackrel{\text { catalysts }}{\longrightarrow}\left[\mathrm{O}_{2} \cdot{ }^{-}\right] \rightarrow{ }^{1} \mathrm{O}_{2} \rightarrow h v+{ }^{3} \mathrm{O}_{2}
$$

In this sequence $\mathrm{O}_{2}{ }^{--}$may play a role in radicalchain propagation under aerobic conditions in the presence of $\mathrm{HSO}_{3}{ }^{-}$whereas ${ }^{1} \mathrm{O}_{2}$ is a light-emitting species operating also under anat.ovic conditions.

Cadenas et al. reported [18], that chemiluminescence with mitochondrial membranes might be related to lipid peroxidation and singlet oxygen formation via the following mechanism:

$$
\begin{aligned}
& \mathrm{LH}+\mathrm{R}^{\cdot} \longrightarrow \mathrm{L}^{\cdot}+\mathrm{RH} \\
& \mathrm{L}^{\cdot}+\mathrm{O}_{2} \longrightarrow \mathrm{LOO}^{\cdot} \\
& \mathrm{LOO}^{\cdot}+\mathrm{LOO}^{\cdot} \rightarrow{ }^{1} \mathrm{O}_{2}+2 \mathrm{LO} \\
& 2^{1} \mathrm{O}_{2} \longrightarrow{ }^{3} \mathrm{O}_{2}+h v \\
& {\left[\mathrm{R}^{\cdot}=\text { starter radical; } \mathrm{LH}=\right.\text { unsaturated fatty }} \\
& \text { acid] }
\end{aligned}
$$

During this sequence, light emission seems also to be due to the decay of intermediarily produced triplet ketones ( $\mathrm{LO}^{*}$ ) according to:

$$
\begin{aligned}
& \mathrm{LOO}+\mathrm{LOO} \rightarrow-\mathrm{L}-\mathrm{L}-+{ }^{1} \mathrm{O}_{2} \\
& -\mathrm{L}-\mathrm{L}-\longrightarrow \mathrm{LO}+\mathrm{LO}^{*} \\
& \mathrm{LO} \longrightarrow h v
\end{aligned}
$$

These findings are in agreement with our results although we cannot identify the light-emitting species with our methods. Superoxide as a reactive intermediate was indicated by decreased luminescence after the addition of SOD. Light emission apparently depends on the content of hydroperoxides: aged LA solutions cause higher rates of light emisions as compared to freshly prepared LA solutions. $t$ - $\mathrm{BuOOH}$ at the same concentration as pure LA yields 3 -fold the light emission in comparison to LA. The light emitting species seems to be generated not exclusively via superoxide, since SOD inhibits light emission only partially in certain experiments. Light emission by the system DP, $\mathrm{HSO}_{3}{ }^{-}$and $\mathrm{H}_{2} \mathrm{O}_{2}$ is all but clear, since neither unsaturated fatty acid nor preformed organic peroxide are added. Hydroperoxide formation from a DP-intrinsic compound and/or ${ }^{1} \mathrm{O}_{2}$ formation must be considered. A most likely mechanism could be outlined by considering the findings reported by Brunmark et al. [19]. They suggest that a light emitting species may be formed by the interaction of a hydroxyquinone with $\mathrm{H}_{2} \mathrm{O}_{2}$ in three steps $(1-3)$ where intermediarily $\mathrm{OH}^{*}$ is formed. The light emitting compound would be a hydroxyquinone in the exited state which emitts photons in the range of $490-570 \mathrm{~nm}$.

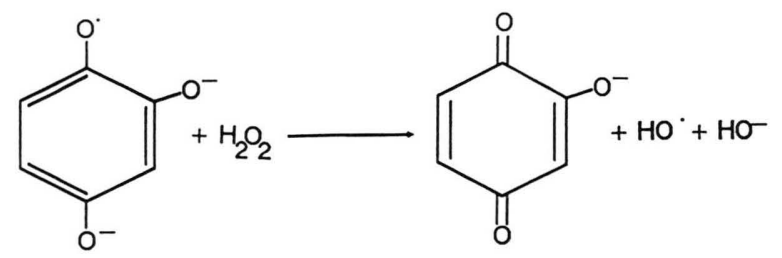<smiles>O=C1C=CC(=[O+][O-])C([O-])=C1</smiles><smiles>O=C1C=CC(=[O+])C([O+])=C1</smiles>

The cooperative mechanism observed in the presence of DP and $\mathrm{HSO}_{3}{ }^{-}$indicates monovalent oxygen reduction and subsequent lipid peroxidation in the presence of an unsaturated fatty acid. In this process, $\mathrm{HSO}_{3}{ }^{-}$is supposed to function both as electron donor and radical propagating agent:
a) $\mathrm{HSO}_{3}{ }^{-}+\mathrm{O}_{2} \longrightarrow \stackrel{\mathrm{DP}}{\longrightarrow} \mathrm{HSO}_{3}{ }^{\cdot}+\mathrm{O}_{2}{ }^{\cdot-}$
b) $\mathrm{HSO}_{3} \cdot+\mathrm{O}_{2}+\mathrm{H}_{2} \mathrm{O} \longrightarrow \mathrm{SO}_{4}{ }^{2-}+\mathrm{O}_{2}{ }^{\cdot-}+3 \mathrm{H}^{+}$
c) $\mathrm{O}_{2}{ }^{--}+\mathrm{DP} \longrightarrow \mathrm{DP}^{\cdot}+\mathrm{O}_{2}$
d) $\mathrm{DP} \cdot+\mathrm{HSO}_{3}{ }^{-} \longrightarrow \mathrm{DP}^{-}+\mathrm{HSO}_{3}$. 
e) $\mathrm{DP}^{-}+\mathrm{O}_{2} \longrightarrow \mathrm{DP}^{\cdot}+\mathrm{O}_{2}{ }^{\cdot-}$

f) $2 \mathrm{DP} \cdot \rightleftarrows \mathrm{DP}+\mathrm{DP}^{-}$

g) $\mathrm{DP} \cdot+\mathrm{O}_{2}^{\cdot-}+\mathrm{H}^{+} \stackrel{\mathrm{SOD}}{\longrightarrow} \mathrm{DPH}+\mathrm{O}_{2}$

h) $\mathrm{O}_{2} \cdot{ }^{--}+\mathrm{O}_{2} \cdot-2+\mathrm{H}^{+} \stackrel{\mathrm{SOD}}{\longrightarrow} \mathrm{H}_{2} \mathrm{O}_{2}+\mathrm{O}_{2}$

As activating principles of DP in reaction a) both nitroaromats and naphthoquinones have to be considered, since both classes of compounds have been shown to undergo redox cycling driving oxidative destructions in the presence of appropriate electron donor molecules [20, 21]. Reactions b)-e) may operate as propagators of the synergistic radical chain reaction observed in the presence of both DP and

[1] W. M. Draper, Chemoshere 15, 437-447 (1986).

[2] R. O. McClellan, Am. Ind. Hyg. Assoc. 47, 1-13 (1986).

[3] R. O. McClellan, Ann. Rev. Pharmacol. Toxicol. 27, 279-300 (1987).

[4] T. R. Henderson, A. P. Li, R. E. Royer, and C. R. Clark, Environ. Mutageneses 3, 211-220 (1981).

[5] T. Handa, T. Yamauchi, M. Ohnishi, Y. Hisamatsu, and T. Ishii, Environ. Intern. 9, 335-341 (1983).

[6] U. Heinrich, H. Muhle, S. Takenaka, H. Ernst, R. Fuhst, U. Mohr, F. Pott, and H. Stöber, J. Appl. Tox. 6, 383-395 (1986).

[7] U. Heinrich, F. Pott, S. Rittinghausen, in: Carcinogenic and Mutagenic Effects of Diesel Engine Exhaust (N. Ishinishi, A. Koizumi, R. O. McClellan, and W. Stöber, eds.), Elsevier Science Publishers B.V., p. $441-455$ (1986).

[8] J. Lewtas, Environ. Health Persp. 47, 141-152 (1983).

[9] P. A. Souththorn, Mayo Clin. Proc. 63, 390-408 (1988).

[10] J. P. Nachtman, Res. Comm. in Chem. Pathol. and Pharmacol. 51, 73-80 (1986).

[11] C. Mottley, R. P. Mason, C. F. Chignell, K. Sivarajah, and T. E. Eling, J. Bio. Chem. 257, 5050-5055 (1982).
$\mathrm{HSO}_{3}{ }^{-} \cdot \mathrm{O}_{2}{ }^{--}$plays an important role as mediator between the DP-redox factors and different $\mathrm{SO}_{\mathrm{x}}$-oxidation states including $\mathrm{HSO}_{3}{ }^{-}, \mathrm{HSO}_{3}{ }^{\circ}$ where sulfate is the final product. Disproportionation of DP' (f) and SOD-catalyzed dismutations $(\mathrm{g}, \mathrm{h})$ represent chain terminating events, where reaction $\mathrm{g}$ ) would be in agreement with the function of SOD as a superoxide-semiquinone-oxidoreductase [22].

Since both $\mathrm{SO}_{2}$ and DP are present in significant concentrations in urban air pollution ( $\mathrm{smog}$ ) the indicated model reactions may be seen as a possible explanation for certain respiratory disorders discussed in context with severe air pollution.

[12] G. D. Peiser and S. F. Yang, Phytochemistry 17, 79-84 (1978).

[13] G. Vogl and E. F. Elstner, Toxicol. Lett., in press (1989).

[14] E. F. Elstner, in: The Biochem. of Plants (P. K. Stumpf and E. E. Conn, eds. in chief, D. D. Davies, ed.), 11, 253-316 (1987).

[15] J. Friend and A. M. Mayer, Biochim. Biophys. Acta 41, 422-429 (1960).

[16] R. J. Youngman, G. R. Wagner, F. W. Kühne, and E. F. Elstner, Z. Naturforsch. 40c, 409-414 (1985).

[17] T. Iwaoka, F. Tabata, and T. Takahashi, Free Rad. Bio. Med. 3, 329-333 (1987).

[18] E. Cadenas, A. Boveris, and B. Chance, Biochem. J. 188, 577-583 (1980).

[19] A. Brunmark, D. Mira, G. Buffinton, and E. Cadenas, in: Free Radicals: Methodology and Concepts (C. Rice-Evans and B. Halliwell, eds.), p. 369-391 (1988).

[20] R. J. Youngman, W. F. Oßwald, and E. F. Elstner, Biochem. Pharmacol. 31, 3723-3729 (1982).

[21] E. Paur, R. J. Youngman, E. Lengfelder, and E. F. Elstner, Z. Naturforsch. 39 c, 261-267 (1984).

[22] E. Cadenas, D. Mira, A. Brunmark, C. Lind, I. Segura-Anguilar, and L. Ernster, Free Rad. Med. Biol. 5, $71-79$ (1988). 